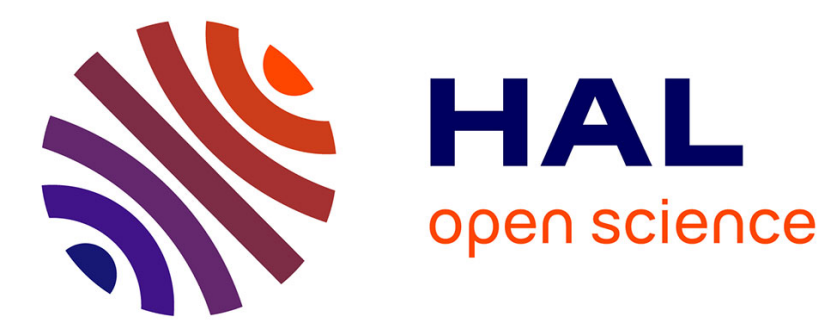

\title{
Story versus history: the contentious creation of the historical videogame Versailles 1685
}

Edwige Lelièvre

\section{To cite this version:}

Edwige Lelièvre. Story versus history: the contentious creation of the historical videogame Versailles 1685. Contemporary French Civilization, 2019, 44 (1), pp.61-79. 10.3828/cfc.2019.4 . hal-02191857

\section{HAL Id: hal-02191857 \\ https://hal.science/hal-02191857}

Submitted on 24 Jul 2019

HAL is a multi-disciplinary open access archive for the deposit and dissemination of scientific research documents, whether they are published or not. The documents may come from teaching and research institutions in France or abroad, or from public or private research centers.
L'archive ouverte pluridisciplinaire HAL, est destinée au dépôt et à la diffusion de documents scientifiques de niveau recherche, publiés ou non, émanant des établissements d'enseignement et de recherche français ou étrangers, des laboratoires publics ou privés. 


\title{
Story versus history: the contentious creation of the historical videogame Versailles 1685
}

\begin{abstract}
Versailles 1685: A Game of Intrigue was a historical videogame released in 1996. It claimed to be the first ludo-educational videogame. This paper intends to highlight the conflictual creation of the game Versailles 1685 through the study of its creation process. During the design of this game, two visions were at odds with each other: a historical approach versus an entertainment approach. According to our findings, this conflict shaped the final gameplay of the game, which led to inconsistencies and the limitation of the players' "historical agency." Although, in 1996, the debate between story and history was private for Versailles 1685, the question of the scientific authenticity of historical games is now a topic of interest for both scholars and videogames players. We hope that this paper will help understand Versailles 1685 and shine a new light on this question.
\end{abstract}

Versailles 1685: Complot à la Cour du Roi Soleil est un jeu vidéo qui a été publié en 1996. II affirmait être le premier jeu vidéo ludo-éducatif. Cet article a pour but de mettre en lumière la création conflictuelle du jeu Versailles 1685 à travers l'étude de son processus de création. Pendant la conception du jeu, deux visions se sont opposées: une approche historique contre une approche de loisir. D'après nos conclusions, ce conflit a façonné le gameplay final du jeu, ce qui a conduit à des incohérences et à la limitation du "pouvoir historique" du joueur. Si, en 1996, la place de la fiction et de l'histoire fut un sujet de débat privé pour le jeu Versailles 1685, la question de l'authenticité scientifique des jeux historiques est maintenant un sujet important à la fois pour les chercheurs et les joueurs de jeu vidéo. Nous espérons que cet article permettra la compréhension du jeu Versailles 1685 et permettra d'apporter un nouvel éclairage sur cette question.

\section{Introduction}

The question of authenticity is a frequent subject of debate in videogames dealing with history (Uricchio), whether players and game critics praise or 
attack this aspect of games. For scholars, it raises the question of how we can talk about history in videogames without altering it. At the same time, some history games claim to be informative and be of educational value. Indeed, recent videogames dealing with historical settings have often tried to obtain a certain level of historical authenticity, although they have not always succeeded. For instance, the well-known historian Jean-Clément Martin, expert on the French Revolution, worked as a consultant on Assassin's Creed Unity (Ubisoft; Fagon). The question of historical authenticity of historical videogames was raised as far back as 1994, during the creation of the videogame we are investigating here: Versailles 1685: A Game of Intrigue, originally released in French under the title Versailles 1685: Complot à la Cour du Roi Soleil.

Versailles 1685 was released in 1996. It was designed by the videogame company Cryo Interactive, the publishing company Éditions Textuel and the conservator-custodian Béatrix Saule from the Palace of Versailles. It claimed to be the first ludo-educational videogame and it was a notable success; according to the game's producer, over two million units were sold across fourteen countries. ${ }^{1}$ However, the debates provoked by the question of historical authenticity were not discussed publicly during the game creation and were never made public, though some inconsistencies raise the possibility that such topics may have been considered.

The "poïetic" methodology (Passeron), which seeks to study the process of creating works of art, provides a way in to this essential debate in understanding historical videogames. It is important to note that this methodology assumes the object studied belongs to the field of art. The debate concerning the "artistic" status of videogames is an ongoing one and it is certainly not our position to affirm this debate is closed (Picard; Parker). However, building my reasoning based on this assumption makes it possible to study Versailles 1685 not only as a technical object, but also as a work of art. Its creation process indeed involved several creative authors who used this project to express their desires and inspiration, and also specific messages about the conception of history and the conservation of cultural heritage.

No academic articles have been written about this game's production so far. The only substantial publication on Versailles is a chapter of La Saga des Jeux Vidéo (Ichbiah). ${ }^{2}$ Unfortunately, this includes no references or methodology, so it was impossible to base any analysis on this study. However, I was able to interview a large number of Versailles authors, who also gave me production documents, such as the game design for Versailles, which were kept preciously for twenty years after the creation 
of the game. In my analysis of these interviews and work documents, I discovered that the creation process of Versailles 1685 was contentious. Two visions were at odds with each other: a historical approach versus an entertainment approach. My findings demonstrate that this conflict shaped the final gameplay of the game, which led to intriguing inconsistencies and limitations to the players' "historical agency," following the leading role of Beatrix Saule, who conveyed her professional background as an art historian and heritage officer in the game.

\section{Presentation of Versailles 1685 and overview of the creation process}

Versailles 1685 was released in 1996 in France under the full name: Versailles 1685: Complot à la Cour du Roi Soleil. The world that is present in the game provides a historical reconstitution of the Palace of Versailles in 1685, at the pinnacle of Louis XIV's reign. Game players must solve a detective case in one day, in order to prevent a madman from setting the Palace of Versailles on fire.

Versailles 1685 is a first-person investigation game, and its gameplay ${ }^{3}$ falls within the "point-and-click" ${ }^{4}$ category. The players never see the character they are playing, and once inside a room, the players cannot make any other moves except for rotating the camera around them. They can examine and interact with objects, talk and listen to non-playable characters (mostly historical figures), or move from room to room. To progress through the game, the players must solve puzzles. They rely mostly on finding and combining objects, while talking with non-playable characters. The design of the game was technically very innovative at the time, as it used Omni3D (see Figure 1), a new system developed by Cryo that allowed players to look around them: a spherical image was generated from every possible point of view (Lelièvre).

Versailles 1685 was co-produced by the Réunion des Musées Nationaux (RMN), Canal+ Multimédia, and Cryo Interactive. It was designed by Cryo Interactive, the Éditions Textuel, and Béatrix Saule from the Palace of Versailles. The RMN is a public body in charge of the management of major French museums, including the Louvre, the Grand Palais, and the Musée d'Orsay. It also managed the Palace of Versailles at the time. Canal+ is a major player in the French television and film industry, and Éditions Textuel were asked to participate in the project, specifically by contributing to the documentary dimension of the CD-ROM with historical and visual 


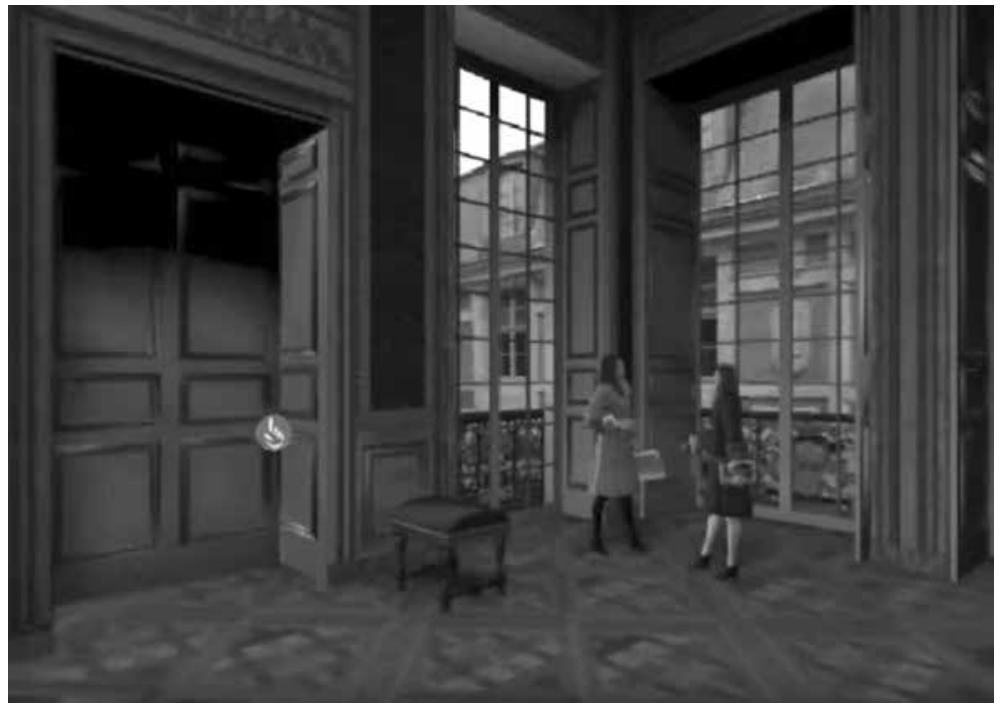

Figure 1 Screenshot from the game Versailles 1685.

content based on their book Versailles au siècle de Louis XIV (de Margerie et al.) published in their collection "Le Temps." Béatrix Saule, ${ }^{5}$ at the Palace of Versailles, provided the project with her academic input. She was not very enthusiastic about it at first, but she was encouraged by Versailles' director Jean-Pierre Babelon. ${ }^{6}$ Her personal interest was to prevent "false history" (Saule, personal interview) in the project. With Sylvie Messinger from the RMN, she worked on the specifications, relying on a scenario created by Philippe Marie. Béatrix Saule wrote the back story to the game, which is based on the same research as her book Versailles triomphant: une journée de Louis XIV (Saule), on which she was working at that time. She specifically described each character, both in terms of their appearance and temperament, and created a background which portrayed a typical day at the Court and the Palace of Versailles itself, as it was in 1685.

A call for tenders was organized for the technical production, at the initiative of the RMN and the Éditions Textuel, who wanted to create a multimedia CD-ROM on Versailles, similar to the one created for the Louvre Museum (Louvre, Montparnasse Multimédia), according to project intern Sébastien Sireaudeau. Emmanuel Forsans, who was producer at Cryo Interactive, was approached by Fabienne Waks from Éditions Textuel as she wanted Cryo to participate in this call for tenders. Even though it was not a standard videogame, Forsans was interested in this project as he considered 


\begin{tabular}{|c|c|c|c|}
\hline 1993 & 1994 & 1995 & 1996 \\
\hline $\begin{array}{l}\text { The RMN asks the } \\
\text { Editions Textuel to } \\
\text { create a cultural } \\
\text { CD-ROM }\end{array}$ & $\begin{array}{l}\text { S. Siraudeau joins } \\
\text { Cryo as an intern and } \\
\text { prepares a prototype } \\
\text { based on the RMN's } \\
\text { specifications and } \\
\text { Philippe Marie's } \\
\text { scenario. } \\
\text { October: Cryo wins } \\
\text { the invitation to } \\
\text { tenders }\end{array}$ & $\begin{array}{l}\text { July: beginning of the } \\
\text { production } \\
\text { December : new } \\
\text { proposal of scenario } \\
\text { by S. Révillard }\end{array}$ & $\begin{array}{l}\text { March: final scenario } \\
\text { and departure of } \mathrm{S} \text {. } \\
\text { Révillard } \\
\text { September: the game } \\
\text { is released }\end{array}$ \\
\hline
\end{tabular}

Figure 2 Timeline of Versailles 1685 creation process, focusing on the context and the scenario.

Versailles very high-end: "I truly saw the opportunity to do something with a real heart, with meaning, with a crazy artistic dimension" (Forsans). Cryo was a French videogame studio which was quite successful at the time (Ichbiah), with a few notable successes such as Dune (Cryo Interactive). Forsans recruited Sébastien Siraudeau, a student in a brand-new Masters in Multimedia as an intern to prepare a prototype. Siraudeau then hired other interns to work on a mock-up, presented their creation at the invitation to tenders and won the call for Cryo Interactive. Their project went far beyond the initially planned documentary CD-ROM. Siraudeau was then recruited as project lead at Cryo, and the game was eventually produced by quite a large team, for that time. The game credits include seventy-four people - forty-seven for Cryo alone - without taking the voice actors into account. The game budget was substantial too, since it ultimately cost 2.3 million Francs. ${ }^{7}$ The production of Versailles 1685 properly began in July 1995 with the photographic shootings of the Palace and the gathering of documentation. As there were numerous problems with Philippe Marie's scenario, Sophie Révillard, who was a production intern at that time, wrote the game design including a new version of the scenario, based on Béatrix Saule's scenario and her own ideas. Marie then left the project, and Révillard was hired to provide a complete game-design document, which was delivered in March 1996. She, too, later left the project and production continued with Saule as sole writer. The game was finally released in September 1996. Thus, we can see that several authors and creators participated in the project. Even concerning the core principle of the project and its main scenario, there were several competing visions (Figure 2). It is possible to group them according to two - conflicting - approaches: the "historical" approach versus the "entertainment" approach. 
The design of Versailles 1685 took place in a rather unusual setting: most historical games are developed under the total supervision of videogame companies, whereas Versailles 1685 was from the start an initiative of a cultural institution, the RMN. In investigating this unusual context for the creative process of a videogame, I based my research on interviews with Béatrix Saule, Emmanuel Forsans, Sébastien Siraudeau, and Sophie Révillard. I made considerable use of Révillard's internship report she wrote for her Master's course ("Vers Un Jeu Culturel") and the game design document ("Game Design Versailles") she provided. Finally, I analyzed the finalized game itself in its French edition, through play.

\section{Conflicts during the creation of the game}

The context of the game's creation was contentious in itself as the idea of creating a videogame was not in the initial brief, as Siraudeau explained: "I think that the base was historical truth because the initiative came from the RMN. So, it was necessary. After, knowing if it was going to be a game. It didn't exist back then. It wasn't actually the goal" (Siraudeau). The idea of creating a videogame and not just a cultural CD-ROM, such as that presenting the Louvre (Montparnasse Multimédia; Waintrop), was suggested for the first time by Siraudeau during the invitations to tender: "I said 'In fact, what you want is to create a videogame, it is a little about that.' It was a bit rough, they didn't really know and, as the same time, they were slightly excited by this aspect of Cryo. It was what they liked about Cryo" (Siraudeau).

Even though Saule was in favor of absolute historical accuracy, she was also motivated by the idea of creating a game and supported this aspect of the project. She forged an idea of the project for herself after discovering Myst (Cyan), ${ }^{8}$ which was shown to her at the RMN: "Then, I understood that we could consider that Versailles was as if we were immerged in a society with its particular laws, and that, then, the ludic spirit of the game will consist of understanding what we could do and what was improper at the Court. So, almost an anthropological approach" (Saule, personal interview). But, at that time, she was not an expert on either multimedia or videogames, which were not as mainstream as they are nowadays. She based her motivation on one project, the game Myst, that she did not actually play. Consequently, she did not know what creating a videogame involved. She thought videogames gave her the possibility of showing the past of 
Versailles in a less fictional way than other media: "I don't like to write false history, so I imagined the project with historical parts, and parts where there will be a real game. We will alternate" (Saule, personal interview).

A total fiction was consequently impossible in the context of the project. A high level of historical authenticity was indeed expected. This approach with as few examples of "false history" as possible complicated the creation of the game, according to Emmanuel Forsans. He considered that Versailles' custodians were not interested in creating a videogame: "Clearly, they didn't care at all about the game. They were the keepers of Versailles. We just couldn't tarnish the image of Versailles, and had to be very cautious with its representation" (Forsans). This conflict between historical authenticity and the fictional dimension of games has been widely discussed by game scholars, as the principle of historical games often raises this issue: "Thus in these cases we see a conflict between the rules of the game and the rules of history: history is designed with the goal of knowledge, understanding and enlightenment in mind; videogames are designed to be won or lost, but their ludic nature - the playing - is the key" (Elliott and Kapell 6). The objective of Saule to maintain historical accuracy was understood, but considered difficult to achieve by Cryo. Indeed, the producer said: "We proposed something consistent and they were beyond consistent. They wanted something real" (Forsans). Sophie Révillard also explained that she considered the game had a value in terms of cultural heritage: "It is actually a realistic vision of history" (Révillard, personal interview). It is interesting to note that both Révillard and Forsans used the term "real" rather than authentic to describe the story of Versailles 1685. According to Douglas Dow, a historical videogame like Assassin's Creed II could be considered a simulacrum:

Upon a closer inspection, however, the Florence of Assassin's Creed II turns out to be not an exact re-creation of the fifteenth-century city, and must be seen instead as a simulacrum, a version of the city that purports to be a true representation of Florence, but that presents a false likeness instead. According to Michael Camille, a simulacrum "calls into question the ability to distinguish between what is real and what is represented." (Dow 218)

In Assassin's Creed II, the developers tried first and foremost to create a good game, even if it involved limiting its historical accuracy.

It seems that the principle of Versailles 1685, was, on the contrary, to create a videogame that would not be a simulacrum, with historical accuracy as the top priority. The authors of this game did not compare themselves 
with other historical videogames at that time, as they were not familiar with any, but at the same time did not want to follow the historical fictions that can be found in literature and cinema. However, Versailles not only depicted mundane daily events in Versailles. The theme of the game is also about stopping a madman from plotting to destroy the Palace, which was an event that never actually happened. According to Saule: "I wasn't probably very fond of the idea of a plot, because there wasn't any plot during Louis XIV's reign [...] so, the history with Scaparella, I thought it was inevitable, but the idea of a plot, I think it was much Philippe Marie's" (Saule, personal interview). The construction of this fictional scenario was highly contentious; indeed Saule stated that "it was made in a painful context, because they presented a scenario to me and I said: 'no, it's not alright,' a second scenario: 'no, it's not alright,' a third scenario: 'no, it's not alright'" (Saule, personal interview). Three scriptwriters worked on Versailles 1685: Marie, Saule, and Révillard, and as a result of these conflicts, two of these scenarists left before the end of the project - Marie and Révillard - and this led to lawsuits.

The first version of the game was written by Marie, hired by the RMN, before Cryo joined the project. Saule said "there was a first writing: the awakening of the King, with the rooster singing. Saint-Simon was there, Molière too. Molière died in '73 and Saint-Simon was born in '75. Everything was commensurate, so I told them: 'listen, we cannot allow this" (Saule, personal interview). She explained that "the difficulty is playing with historical characters when we know what happened to them. So, I didn't want to do things that didn't happen" (Saule, personal interview). To resolve these inconsistencies, Saule wrote a very tight synopsis including a description of each character at the Court, which constrained their role in the game: "I made a chart of the characters, and what it meant in term of their physique, of their thinking, their state of mind, who were their friends and allies, who were the enemies, etc" (Saule, personal interview). According to Révillard's internship report, they nevertheless agreed on the fantasy aspect of the scenario at this point, as the game was supposed to "take a firmly fantasy position, with time travel as starting point" ("Vers un jeu culturel").

In the initial version, the player's character was supposed to be from today, and be sent through time by a historian from the French National Library. The historian had discovered the presence of Alias, a "virus from history" in 1685, and had charged the player-character with preventing Alias's plot against the Palace of Versailles. Siraudeau suggested that Révillard could 
write an augmented version of Marie's initial scenario, while she was still a production assistant. In her "proposal for the scenario," that she presented to Cryo in 1995, she wrote that three principles should form the basis of all her work on the scenario: "The presence of a virus from history, Alias. The idea of a plot, set up by this character. The respect of the integrity of historical characters" ("Vers un jeu culturel") However, she did not ultimately adhere to the first of these rules, as in the final version she gave up on time travel, and the conspirator becomes a contemporary Venetian noble, Scaparella.

In addition to the overall scenario, the question of which role the playercharacter would have was also much discussed. In her report, Révillard explained that, initially, it was envisaged that the player could embody any historical character in the Palace: "For Versailles, it was suggested that the player and their adversary (who creates the starting point justifying the game) could "borrow" the bodies of historical characters. Thus, we didn't touch their historical integrity: they weren't driven by their will but "possessed' by the player" ("Vers un jeu culturel"). However, a second option was chosen: "the player is Bontemps, responsible for the intendance and the security of the Palace. He seeks naturally, in a first phase, to know what is happening, then, in a second phase, to solve the problem (dismantle the plot), without disturbing the day of the King" ("Vers un jeu culturel"). Saule said the idea to choose Bontemps and his role was hers. But, this role had to evolve again, as there was too much constraint on this character. Siraudeau explained that playing Bontemps would have made him need to do "impossible things."

Révillard consequently worked on identifying what could be a different feasible role of the player-character. She considered defining it as her main input to the game:

My contribution, through a dialogue with Saule, was to identify what was the player's role. We encountered a lot of questions. Should it be a historical character? Could it be? And the answer was no, because it was impossible to change history. It had to be someone with access to the Palace, while the Court was supposed to be with the King. And it was not a stranger, because he would have been arrested by the guards. (Personal interview)

It was finally decided that the player-character would be a Blue Guard. Although Saule was the proponent of a very strong historical approach, none of the other creators of the projects were in fact solely interested in entertainment: it was clear from the start to all that it was going to be a cultural CD-ROM. But the interest in entertainment was strong, and not 
only at Cryo. It looked like Philippe Marie, for example, the first writer hired by the RMN, was actually more interested in fiction than history. On the other hand, Révillard who was hired by Cryo to write the final game design had a historical background and considered herself a historian. It is thus important to note that there was not a frontal opposition between the videogame company on one side and the cultural institutions on the other side. It was a conflict between two approaches, with differing intensities, rather than two distinct teams of people constantly fighting against each other.

\section{Impact on the final gameplay of Versailles 1685}

The historical authenticity demanded by Saule was acted upon by the team and especially by Révillard, who wrote:

The fact that the form isn't apparently serious doesn't mean there should be a demarcation between a strict reconstruction of the space and a superficial scriptwriting. On the contrary, it is essential for the scriptwriting to be as respectful of history as the reconstruction of the physical space. In this way, the reconstructed place won't just be a simple background. ("Vers un jeu culturel")

My analysis of the game informed by the interviews I conducted suggest that this had a significant impact on the final version of Versailles 1685.

The role given to the player was ultimately that of a Blue Guard of the Palace, Lalande, as explained by Révillard:

And you, you are a Blue Guard, it is the solution that has been chosen. So, a security agent, but anonymous, by opposition to the Head of security who was Bontemps and who was a historical character. And so, we had the keys to doors. And we could go were where we wanted to, except where the King was, precisely, and the Court. (Personal interview)

Even although she was not a seasoned game designer, Saule cleverly used the limitations of player agency to teach the player-character the etiquette of the Court and pass on her knowledge of seventeenth-century Versailles. The idea of the Blue Guard character was thus to give the player limited but legitimate agency inside the Palace. The price paid for this was to have a very weak character. Lalande's role is indeed as historically weak as can be. Although Blue Guards existed, Lalande is an invented name. He was designed as a standard character of the Palace, who did not affect history. 
Lalande is also very weak fictionally: he has no back story, no feelings, just a mission.

After discussing the research presented in this article, French psychiatrist and game scholar Yann Le Roux has suggested during a personal interview that Lalande's role is close to that of a museum custodian. Like such a person, he is the invisible guardian of Versailles. In addition, the use of this Blue Guard character prevents the player from interacting with the King. It is a way of limiting the "historical agency" of the player: although the player can interact with the Palace and the Court, he has no impact on important historical facts, like major events and historical characters' behavior. These facts are essential for history considered as "single chronological narrative" (Kee) and what Granatstein's calls the "Best Possible Story" (Granatstein). The King was, however, presented, but only in scenes that were subsequently cut. Players were not able to play with the King and the Court, and they had to play on the periphery. According to Brown, quoted by Elliott and Kapell, "by constructing a virtual past and granting the player agency within it, video games have become the ideal medium for teaching the lesson of contingency [the effect of past actions on present realities]" (11). In Versailles 1685, the authors took exactly the opposite approach in limiting the strength of the player's agency in the game and used instead the simulation aspect of videogames to teach their lesson.

Although the scenario, the characters, and the Palace reconstruction were carefully crafted and supervised, the riddles and puzzles of the game did not receive the same treatment. This was the result of both the lack of interest and feeling of lack of legitimacy of Saule in this area of game design: "But I considered that the games were something special. And I can simply say that they showed them to me so I could say 'here, it's alright $[\ldots]$ well, we respect the theme of the game.' But I didn't go further [...] I can tell you that I never played" (Personal interview).

Despite this objective of historical accuracy, the game is not entirely devoid of historical inconsistencies, according to Révillard. She explained that creating a historical game

is a dialogue between the main authors, actually. It is like in cinema [...] It is really a dialogue between the will to be on one hand flirtatious, the aspect understandable by the public, and on the other hand, the historical truth. And it is true that, even in the game Versailles, where we were extremely serious regarding history, there are moments where there are small inconsistencies. This is certain. (Personal interview) 


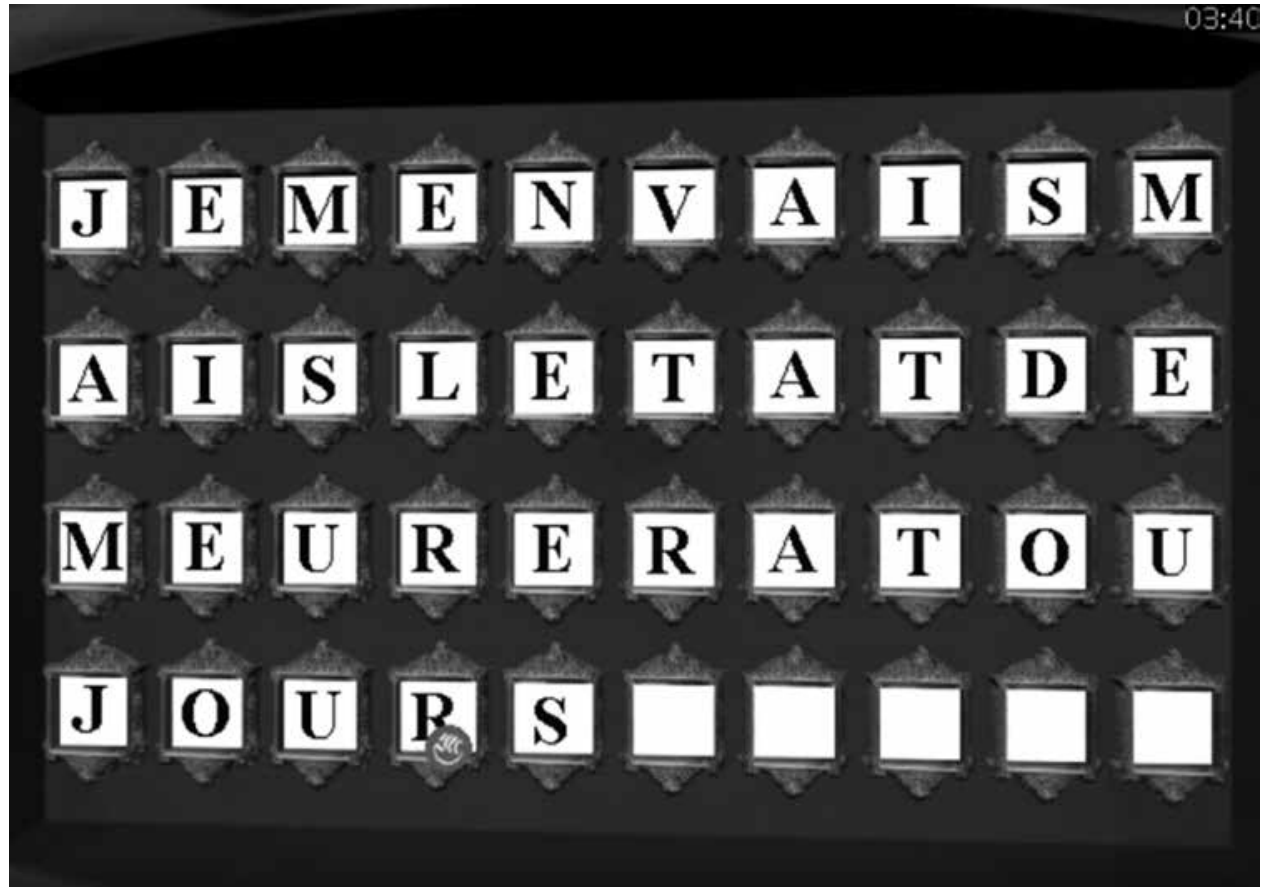

Figure 3 Screenshot from the game Versailles 1685, final riddle.

After a careful playtest of the game, these inconsistencies are not obvious, though, and they reside mostly in the riddles. The last riddle of the game is probably the most complicated and is especially memorable. Solving it involves needing to use all the parts of the puzzles collected in previous levels. However, my analysis suggests that it is also where the biggest inconsistency of the game is to be found. Before the end of the game, the player must find a succession of letters, with the help of a "memorandum." Each letter must be found in one part of Aesop's fables, which the player is able to find in Versailles's labyrinth. The player must find the bomb mechanism (Figure 3) and, on its interface, choose the letters for each square to win the game. Failing to do so is one of the few ways to lose the game.

The solution was "jemenvaismaisletatdemeureratoujours." As the letters had to be entered independently, without punctuation and accentuation, it was not so easy to understand the sentence. The sentence they formed was supposed to spell out "Je m'en vais, mais l'État demeurera toujours": "I am leaving, but the State will always remain," which were the last words of Louis XIV (see Dangeau). Of course, in 1685 the King was still young 
and far from his death. One can then wonder why we would find his last words in the game. Révillard explained that this was related to the initial idea of including an element of time travel in the game scenario, which was completely absent in the final version of the game:

for instance, the mechanism that burns the Palace, it is possible that it exists, but it is in dealing with the spatiotemporal paradox. ${ }^{9}$ It is true that, at the beginning, we had a character coming from the future and who intended to wreak havoc in Versailles. This is how he knew the last words of the King, which is the sentence to stop the mechanism. And this has been removed in last resort, so we have a paradox here. It means that the Palace isn't destroyed so the king does not die, but the sentence is still the last words of the King. (Personal interview)

Although this is a famous sentence in French history, it is not certain that all players recognized it or even understood the meaning of the sentence. As a young player, I personally was initially very confused by this sentence and indeed only fully understood its meaning and significance after discussion with the authors of the game. It is also interesting to note that this specific sentence has not been kept in translation. In English-language versions of the game, the phrase is "it is not in the power of kings to attain perfection." Consequently, rather than being a voluntary divergence from history, this inconsistency seems to be the result of the numerous versions of Versailles' scenario, conflict between the authors, and lack of interest of Saule in this part of the game, that has ultimately been neglected.

\section{Historicity versus playability versus technology}

Even with the small inconsistencies in the riddles, one can wonder whether Versailles 1685 managed to achieve absolute historical accuracy. Contrary to most historical games, for which "playability can be seen to overpower historicity" (Elliott and Kapell 13), Versailles 1685 went very far in terms of historical authenticity. It is probable that the specific context of the project played a large part in this historical authenticity. Béatrix Saule was indeed not in the position merely of adviser, which was the role Jean-Clément Martin played in Assassin's Creed, but was in fact a writer and decision maker, although she was not managing the financial element of the project. As the project was commissioned by a cultural institution and not by a videogame editor, she had legitimacy in vouching for historical authenticity. Her position was also different to that of being simply a history 
lecturer or a history researcher: a custodian is affiliated to a specific historic monument. She had, of course, a mission of sharing history, but was not in charge of "training" new historians. One of her goals, as a custodian, was to protect the cultural heritage of Versailles. It was very different to that of Kevin Kee, a history teacher and scholar, in his MaP project (Kee), for instance. In this historical videogame, he was indeed trying to teach his students what the job of a historian is.

Although historicity often prevailed over fiction and playability in Versailles 1685, some concessions to historical accuracy were made, but not to improve these particular aspects of the game. Concessions were more related to technological constraints, which were accepted as impossible to overcome by Saule, as she explained:

There was a pitfall. I said: "Versailles was crowded," and I was very happy, because, thanks to the virtual aspect, we would have a lot of characters [...] And I said: "so you will clone them." At some point, they couldn't, because it would require an impossible number of calculations. And, in addition, we had the mirrors. It meant they had to compute the reflections in the mirror. And there was a scene in the Cabinet du Conseil. But in the reign of Louis XIV, the Cabinet du Conseil [...] was integrally paneled with mirrors. So then they threw in the towel, saying "no, we cannot do infinite reflections like that." (Personal interview)

According to Uricchio, there are two types of historical games. Some "deal with a particular historical event - a race, a battle - allowing the player to engage in a speculative or 'what if' encounter with a particular past" (328). The other games contrastingly, "deal with historical process in a somewhat abstracted or structural manner [...] historically situated games in which a godlike player makes strategic decisions and learns to cope with the consequences, freed from the constraints of historically specific conditions" (328).

While Saule was working on the game, she was also writing her book Versailles triomphant: une journée de Louis XIV. The editorial position of the book, as stated by its publisher Flammarion, was to present a typical day at an extraordinary site of French history. This firm stance was used in Versailles 1685, albeit with a different period in mind. The choice of the period was not merely coincidental, as it was ideal concerning the state of the Palace, the behavior of the Court and the King, according to Saule. However, choosing a "typical day" from this period where nothing exceptional happened apart from a single key event, helped the authors to limit the players' "historical agency." Versailles was not about historical 
structure either, as the authors were more concerned by historical facts than process. The position of Flammarion regarding this book consequently offered a different position to the game, outside of the categories described by Urrichio. However, it is clear this game exemplifies what Kee termed "first-order knowledge of history." According to Kee (430), this concept draws on a key idea of Holt and Wineburg:

Although few would argue with the importance of names, dates, and events, these give students only a partial understanding of the discipline of history. Recent scholarly research has focused on the necessity of supplementing "first-order knowledge of history" (content) with "second-order knowledge," which moves students beyond the names and dates of history to an understanding of the skills of historical practice such as generating, corroborating, representing, and assessing interpretations of the past. (Kee 430)

The actual work of a historian was absent from the game. There was no debate or questioning on the point of view on history of Saule by the production team during the creation process. The game was sanctioned by an institution and its "official" historian and consequently considered objective by the team creating it. So, it seems that the goal of ensuring historical authenticity also paradoxically challenged history as a scientific discipline in this game. In addition, a telling anecdote from interviews with Saule makes us consider that the game was not only created to educate players about history, but also to inform them about the role of the historical custodian, albeit unconsciously. Most of the time, the unsuccessful player of Versailles 1685 does not lose but just gets "stuck" in a chapter, but on a number of occasions, there was actually a possibility of "Game Over." In the commercial version of the game, losing and finding oneself in a game-over situation resulted in seeing an engraving of the Palace, slowly burning as the paper of the print was consumed by flames. But Cryo had also created a different "Game Over" video, which used the same 3D model of the Palace that was in the game, and set an effect of fire around it. They did not share this with Saule until the press conference for the release of the game, as she told me in an interview:

This is when they showed me the last sequence with the burning Palace [...] And then, I told them that I absolutely didn't want it to be this way [...] I talked to Jean-Pierre Babelon, ${ }^{10}$ telling him that we, we were custodians, whose job was to save things, and we were not going to make a game that would persuade people to burn and destroy. Because, I said, an impressionable mind could be influenced by these images and that shouldn't be... 
Anyway, I always said that I didn't want it and I don't want it. So, I called Irène Bizot. ${ }^{11}$ I told her: "Listen, it is really simple, I will send the bailiffs in, I will ask for the seizure of the game. We are absolutely against." The game was being made in Germany, it was being pressed in Germany. And so, they had to destroy the first version. (Personal interview)

The only copies of the game with these images were consequently those given to the journalists present on that day. This anecdote shows both how much power images of $3 \mathrm{D}$ reconstruction had in the eyes of Saule, as well as her own power and rigorous position on protecting the Palace's image. The fact that the "Game Over" is the destruction of the Palace rather than "merely" the killing of the King can also be attached to the historical research-based endorsement given by Saule, as professional heritage custodian protecting a site of history rather than history as a discipline. One can even wonder whether Saule was trying to create an attachment toward the monument, in a dynamic of cultural heritage conservation. ${ }^{12}$ During the creation process, the attention given to the Palace was indeed significantly higher than the attention given to riddles, whereas they are the core gameplay mechanism of Versailles 1685.

\section{Conclusion: Versailles' stance on historical videogames debate and the lessons of the creation process study}

The creation of Versailles 1685 gave rise to a conflict between two competing visions: a historical approach and an entertainment approach. Counter-intuitively, these approaches were successively defended by different members of the team on both sides during the project. According to our findings, this conflict shaped the final form of the game, which was characterized by very high historical accuracy (with small inconsistencies) and certain limitations to a player's "historical agency" through the choice of the player's role as a Blue Guard. Béatrix Saule, main scriptwriter and custodian of the Palace of Versailles, steered the game toward focusing on facts and conservation of the Palace as a historic monument rather than the investigation of the processes of history as an academic discipline. She consequently integrated into the game her duties as a conservatorcustodian, which were very different to those of an academic historian.

What is also noticeable is the quantity of work and investment this project required. The conflict, in the end, looks like the visible part of the passion and conviction that animated the creators of Versailles 1685, 
and illustrates the artistic and personal involvement of the writers in this videogame. Although the project was at times highly contentious in its creative processes, it is important to note that the contributors to it who were interviewed for this research all emphasized the pride and pleasure they felt while working on this game. They also talked about the bond they formed and even their wish to pursue this "adventure." Although the more visible creative conflicts seem to have played a role in in the ultimate shape of the game Versailles 1685, it is also probable that this special bond between the game's authors also had a significant impact on the creative process and could lead to an interesting and complementary point of view on the creation process of Versailles 1685 in further research.

\section{Université de Versailles Saint-Quentin-en-Yvelines}

\section{Notes}

1 This data was provided from memory by Emmanuel Forsans, producer of Versailles 1685 and member of Cryo, on 22 July 2015. We have so far been unable to collect verified or more accurate data on the game sales.

2 Uricchio also presented Versailles 1685 in his paper "Simulation, History and Computer Games," but his argument is quite vague and based on an online paper that is not available anymore. Although the rest of Uricchio's paper is very detailed, the part on Versailles gives the impression that he may not have played the game. He indeed wrote "Versailles 1685 provides near endless possibilities, and thus outcomes for the king and his minions within the confines and the palaces," whereas there are only two possible outcomes.

3 The term gameplay associates the "game" which is similar to the "ludus" described by Caillois and "play," a game without rules that is closer to the "paida" (Caillois). This association highlights the tension between the game rules and the player's appropriation of these during a game. In this sense, the term gameplay describes the experience resulting from the negotiation between the game rules and the player's behavior. By extension, this term is used by game designers to define the expected user experience. According to Jesper Juul, gameplay is the definition of rules and players' interaction opportunities (Juul).

4 Point-and-click gameplay refers to games in which interactions are mainly triggered by mouse-clicks. Usually, these games are graphic adventure games, like Myst (Brøderbund Software 1993).

5 Conservator-custodians ("conservateur" or "conservatrice du patrimoine") in France are not regular historians as they are attached to a monument or museum rather than to a university. Their mission is to preserve and valorize their monument or museum, as well as organizing exhibitions. Their education is specific and this job requires to pass a competitive exam. http://www.onisep.fr/Ressources/UniversMetier/Metiers/conservateur-conservatrice-du-patrimoine (in French). 
6 In the interview with Béatrix Saule (3 September 2015), she reported that Jean-Pierre Babelon told her, about the multimedia project on Versailles: "Listen. It will be done anyway, because the financial plan is validated, and it will be done without you, and you will be very angry that it was done without you." Translated by the author from French, as all other personal interviews quoted in this paper.

7 Which amounts to $€ 438,000$, without taking the cost of inflation into account.

8 Myst was a very successful point-and-click puzzle videogame in which the player roams a seemingly deserting island, looking for answers.

9 It makes sense if the conspirator planting the bomb travels through time and had access to Louis XIV's last words.

10 Babelon was the director of the Palace of Versailles at that time.

11 She was the general manager (administrateur général) of the Réunion des musées nationaux at that time.

12 This idea was suggested by Thibault Le Hégarat, French history scholar specialist of cultural heritage.

\section{Videogames and CD-ROM cited}

Assassin's Creed II, Ubisoft Montréal, 2009, Ubisoft.

Assassin's Creed Unity, Ubisoft Montréal, 2014, Ubisoft.

Dune, Cryo Interactive, 1992, Virgin Interactive.

Louvre, Montparnasse Multimédia, 1994, Réunion des Musées Nationaux.

Myst, Cyan, 1993, Brøderbund Software.

OFabulis, Lelièvre, E., 2014, Université de Versailles Saint-Quentin-en-Yvelines, Centre des Monuments Nationaux, Emissive.

Versailles 1685: Complot à la cour du Roi Soleil, Cryo Interactive, Canal + Multimedia, Éditions Textuel, la Réunion des musées nationaux 1996, Cryo Interactive, Canal + Multimedia.

\section{Works cited}

Caillois, Roger. Les Jeux et Les Hommes. Gallimard, 1992.

Dangeau, Philippe de Courcillon (1638-1720). Mémoire sur la mort de Louis XIV. Didot frères, fils, 1858. gallica.bnf.fr.

de Margerie, Anne, Isabelle Backouche, Marie Desplechin, and Joël Cornette. Versailles au siècle de Louis XIV. Réunion des musées nationaux, 1993.

Dow, Douglas N. "Historical Veneers: Anachronism, Simulation and History in Assassin's Creed II." Playing with the Past: Digital Games and the Simulation of History, edited by Matthew Wilhem Kapell and Andrew B.R. Elliott, Bloomsbury Academic, 2013, pp. 215-231.

Elliott, Andrew B.R., and Matthew Wilhem Kapell. "Introduction: To Build a Past That Will 'stand the Test of Time' - Discovering Historical Facts, Assembling Historical Narratives." Playing with the Past: Digital Games and the Simulation of History, edited by Matthew Wilhem Kapell and Andrew B.R. Elliott, Bloomsbury Academic, 2013, pp. 1-29. 
Fagon, Louis. "Saisir l'histoire par les jeux vidéo, compte-rendu de la séance du 30 Novembre 2015 Autour de Jean-Clément Martin." re/lire les sciences sociales. 3 Dec. 2015. Web.

Forsans, Emmanuel. Personal interview, 22 Jul. 2015.

Granatstein, J.L. Who Killed Canadian History? HarperCollins, 1998.

Holt, Thomas C. Thinking Historically: Narrative, Imagination, and Understanding. College Entrance Examination Board, 1990.

Ichbiah, Daniel. Bâtisseurs de rêves: enquête sur le nouvel Eldorado des jeux vidéo. F1rst, 1997.

Juul, Jesper. "Half-Real: A Dictionary of Video Game Theory." Half-Real: A Dictionary of Video Game Theory. 2005. Web.

Kee, Kevin. "Computerized History Games: Narrative Options." Simulation \& Gaming, vol. 42, no. 4, 2008, pp. 423-440.

Lelièvre, Edwige. "OFabulis and Versailles 1685: A Comparative Study of the Creation Process behind Video Games on Historical Monuments." DiGRA/FDG '16: Proceedings of the 2016 Playing With History Workshop, vol. 13, no. 3, 2016. Web.

Parker, Felan. "An Art World for Artgames." Loading... The Journal of the Canadian Game Studies Association, vol. 7, no. 11, 2013, pp. 41-60.

Passeron, René. La naissance d'Icare: éléments de poïétique générale. Ae2cq, 1996.

Picard, Martin. "Les enjeux esthétiques du jeu vidéo : entre art, stylistique et interactivité." Sciences du jeu, vol. 6, 2016. Web.

Révillard, Sophie. "Vers un jeu culturel." Internship report. Mastère MultimédiaHypermédia ENSBA/ENST, 1995.

—."Game Design Versailles.” Mar. 1996. Unpublished electronic document.

—. Personal interview, 29 Jul. 2015.

Saule, Béatrix. Versailles triomphant: une journée de Louis XIV. Flammarion 1996.

- . Personal interview, 3 Sep. 2015.

Siraudeau, Sébastien. Personal interview, 3 Sep. 2015.

Uricchio, William. "Simulation, History and Computer Games." Handbook of Computer Game Studies, edited by Jozef Frederik Ferdinand Raessens and Jeffrey H. Goldstein, MIT Press, 2005, pp. 327-338.

Waintrop, Edouard. "Il a mis le Louvre dans votre ordinateur." Libération. 28 Dec. 1995. Web.

Wineburg, Sam. Historical Thinking and Other Unnatural Acts: Charting the Future of Teaching the Past. Temple UP, 2001. 